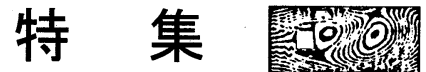

\section{本四架橋に向けた耐風技術の変遷（個人的な係わり） \\ Primal Progress of Wind Resistant Design for Honshu-Shikoku Bridges}

成田信之*

Nobuyuki NARITA

\section{1.はじめに}

編集担当の平野先生より，培われた技術の変遷と本 四での集大成をおこなうようにとの執筆依頼が“断る な”との注釈付きで頂いた。それほど大きな課題につ いて執筆する自信もないし，また，怪しいことを書き そうで心配である。そこで, 個人的な係わりに限らせ ていただきたいと思っている。いずれにしても，資料 の再調査もせず, 個人の記憶に沿って筆を進めるため, 特に数值に関しては誤りが多いのではないかと不安で あるが，文脈をご理解頂くことでお赦しを頂きたい。 また文末には，これからの橋梁の維持管理についての 考えを述べたいと思う。

\section{2. 最初のかかわり}

筆者が長支間の道路吊橋を知ったのは, 昭和 35 年に 北九州市の洞海湾に架けられた若戸大橋 $(89+367+89 \mathrm{~m}$, 平成 2 年に 4 車線に拡幅) の風洞害験を通じてである。 当時, 昭和 15 年 11 月に竣工から僅か 4 ケ月後に強風 で落橋したタコマ橋をニュース映画で観て, 戦後に論 文を書かれ，いわゆる換算曲げ剛性・㧖れ剛性の考えを 提案された恩師の平井 敦先生は若戸大橋の耐風設計 を引き受けられ, 後に中央大学に移られた岡内 功先 生の直接指導の下で同期生 2 名とともに, 卒業研究と して風洞実験を手伝った。

実験に使用した風洞は航空学科所属のものを借用し た。円形吹出し口 $(1.5 \mathrm{~m})$ の開放型の回流式風洞で, 冬の冷気のなか部分模型を吊るした測定部の上部に置 かれた吊線式天秤で三分力を測定し，また，バネ支持
模型を使ってフラッタ試験を行った。また, アルバイ ターとしてY社に赴き, 島田静雄先生が行われた本橋 の架設計算の手伝いをした。

長大橋梁の風洞実験の実施例はわが国でも少なく, 参考文献としては Prof. F.B.Farquharson が旧タコマ橋 の落橋原因の追究と新橋の計画のために実施した部 分・全橋の風洞実験結果を取りまとめた 4 分冊からな る報告書が唯一のものであった。

卒業後建設省土木研究所に勤務したが, その頃にな ると本州四国連絡橋の架橋計画も実現に向けた調査研 究が具体的に動き始め, その業務の一環として再び若 戸大橋に関係することとなった。本橋については竣工 時の動的構造特性すなわち固有振動数と減衰特性を実 測した。それまで吊橋など柔形式橋梁の動特性は，山 間地の中小橋について人力加振によって得られた微小 振動から得られたものが大部分であった。若戸大橋の 場合は，交通開放直前の機会を捉えて自衛隊のトラッ ク群による静的載荷試験と 2 対の不平衡重錘を鉛直面 内に回転させる方式の起振機による動的載荷試験が行 なわれた。その結果から，本橋の補剛トラスが大変大 きな㨭れ剛性をもっていることを知らされた。

若戸大橋のほかにも国内の中小支間の吊橋や斜張橋 について，特別に製作した起機振を用いて振動特性を 計測して歩いた。その結果, 振動減衰特性は橋梁それ ぞれの架設条件に大きく影響されて一定のものでなく, また気温の変動の影響も受けるものであることが分か った。そこで, 耐風設計基準には安全性を考慮して小 さ目の値を採用した。 
若戸大橋の風洞実験と実橋実測で長大吊橋の勉強を させられたが，そのあいだの時期すなわち大学院時代 には, 列車走行時の吊橋応答測定実験にも参加した。 秋田県能代の近傍に架設された鉄道吊橋を木材搬出用 のトロッコ列車が通過するときの振動を計測するもの で若き日の伊藤 學先生などと過ごした。秋田の方言 が聴き取れないために列車の通過時刻が判らず, 計測 準備に困ったことを記憶している。

その後, 本四架橋の計画調查にも参加させて頂いた。 当時, 関係自治体による本四架橋計画の誘致活動は盛 んで, 神戸・鳴門ルート, 宇野・坂出ルートそれに尾道・ 今治ルートの各ルートは個別に調查活動を行っていた。 昭和 34 年の夏に香川県の依頼を受け, 後に武蔵工大に 移られた西脇威夫先生を中心に, 橋梁研究室のメンバ 一は県庁の一室に缶詰めになり，40日ほどをかけて宇 野・坂出ルートの計画設計をおこなった。設計の実経験 の全くない筆者は指示されるままに懸命に手動計算機 を回した。時間的な制約もあり構造形式別に代表的支 間の橋梁を 2,3 概略設計し, あとは内捜して材料・寸 法を推定する方法を採った。このことは筆者にとって 貴重な経験となった。本四連絡橋の事業が完成した現 在, 機会があれば実橋の数値と比較してみたいと西脇 先生とも語り合っているが, 未だ実現していないのは 残念である。

\section{3. 土木研究所でのかかわり}

建設省に就職する際，現場で仕事をしたいと業務の 希望を提出したが, 配属先は土木研究所であった。そ して入所 1,2 年の間は応力凍結法を用いた光弾性実験 によるダムの応力解析や道路橋の耐震設計の手伝いな どをして過ごした。その後本四連絡橋の建設計画は大 きく動き出し, 所属の構造研究室は長大吊橋の耐風と 耐震の問題に専念することとなった。台風と地震に耐 える中央支間 $1,000 \mathrm{~m}$ の吊橋の建設を可能とせよとい うのが最初の命題であったように記憶している。どう やら若戸大橋の耐風設計などを䪤っていたのが配属の 理由だったのかも知れない。

初期の段階では, 耐風問題の実験は大学への委託研 究で済まし, 専ら文献調查を進めた。当時, アメリカ での吊橋を中心とした長大橋梁建設の時代は既に頂点 を過ぎており，新規なものはフランス・イギリス・デン マークなどヨーロッパに見られた。設計風速とガスト 応答の研究に先進的な業績をあげられていたのを知り， 厚かましくも学位論文のコピーの送付を依頼した Prof.
A. G. Davenport, セバーン鉄道橋に取り付けた自然風 の鉛直迎角観測機器についての議論をした Mr. C. Scruton などを想い出す。特に Mr. C. Scrutonにはその 後の留学に際して大変世話になった。

さて，建設省と日本国有鉄道からの委託を受けて土 木学会に昭和 37 年 1 月に「本州四国連絡橋技術調查委 員会」が発足し, 昭和 38 年 1 月にはその下部組織とし て「耐風設計小委員会」が設置されて本格的技術検討が 開始された。小委員会には土木·建築·気象・航空・電 気等の分野から専門家を迎え, 昭和 40 年 5 月には第 1 次報告書を取りまとめ, 付属資料として「耐風設計指針 (1964)および解説」を上梓した。こうして本州四国連絡 橋の耐風設計に関してよるべき基準を示すと共に, 解 説書も作成してその時点での諸研究の結果を総括して 指針の内容の基礎的な考え方を明らかにした。耐風設 計基準は研究の進展に合わせて順次改訂され, 実橋の 設計に生かされた。とはいえ, 当初は強風の観測記録 も満足なものがなく, 兵庫県垂水に建設された気象観 測塔（塔高 $80 \mathrm{~m}$ ）に台風が接近するたびに観測小屋 に泊り込み, 強風の吹き荒ぶ中で矢羽根式風向計（バ イベーン）や超音波風速計を用いて風速の鉛直分布, 風の鉛直迎え角, ガストなどの測定をおこなった。そ の成果は初期の設計風速や鉛直迎元角の基準化の基礎 資料を提供した。設計風速については海上部での観測 値がないため, 気象官署と観測船の風速比を気象官署 のそれに乗じて決めるといった方法を採ったりもした。 こうして 3 つのルートの設計の基本とする風速は異な った值を採ることとした。

因みに, 道路橋示方書に規定されている設計風荷重 は島嶼も含めて一定値を採用しているが, 本来, 設計 風荷重は風速の再現期待值, 構造物の耐用年数, 非超 過確率, 構造物の規模 - 構造特性等々数多くの因子を 考慮して決定されねばならず，それらの基本となるも のは架設地点における風速の再現期待値である。そこ で，全国の 163 気象官署の観測資料を基に再現期間 $20,50,100$ 年の 10 分間平均風速と瞬間風速の再現期待 值を算定した。その結果, 地域によりその差が大きい ことが分かった。特に最近は地球環境の変化の影響の ためか, 従来の統計值が単純に適用し得ない現状にな っているようにも思われるので是非とも再検討して， 全国を一律に規定することの可否を見直す必要がある と思っている。

その後, 実験施設を持ち自前で実験を行わ站ばなら ないと言うことで, 航空関係の研究者に教えを乞いな 
がら風洞施設を建設した。橋梁試験に専用すると言う ことで「橋梁試験用風洞」と名付けた。プロトタイプ の主構間隔を $30 \mathrm{~m}$ と想定し, その $1 / 100$ 縮尺の模型を 採用することとし, アスペクト比を 6 程度として, 閉 塞率, 静圧勾配などの影響を考慮のうえ, 最終的に測 定部は $1.8 \times 3.0 \mathrm{~m}$ で $30 \mathrm{~cm}$ の角切りのある縦長の断面 とした。当初この風洞には一様風のみの特性を持たせ, 将来的には脈動風も吹かせうる機能を持たせた設計と したが, 筑波研究学園都市への移転計画が浮上する至 り実現はしなかった。また, 後に述べる英国での全橋 試験に刺激されて, 縮流胴を可傾式として吹き上げ・ 吹き降ろしの気流を吹かして, 模型を傾ける必要のな い状態で全橋模型実験の可能な吹き口 $32 \mathrm{~m}$ の超大型 風洞の計画も提案したが予算上の制約から実現しなか った。

架橋計画の調查研究は急速に進展したが，いきなり 超長大橋梁が実現したわけではない。若戸大橋がわが 国初の本格的道路吊橋として竣工してから本四連絡橋 計画最後の明石海峡大橋に至るまでの 35 年間には, 多 くの吊橋あるいは斜張橋が架設され，いわゆる柔形式 橋梁の耐風設計に関与して経験を積むことができたこ とは幸運であった。しかもその支間長は年とともに漸 次伸張し，一橋ごとに設計の成果を実橋で確認しなが らステップ・バイ・ステップで調查研究を進めること ができたのは大きな自信ともなった。

上にも触れた Mr. C. Scruton はアメリカ型のトラス 補剛吊橋に替わる箱桁補剛吊橋を案出し，セバーン橋 に適用した立役者として Sir. Gilbert Roberts 卿ととも に注目をされていた。氏は既に昭和 21 年頃から航空機 の格納庫を利用してセバーン橋の全橋模型実験（この 模型のプロトタイプはトラス補剛橋で最終的にはフォ 一ス道路橋に採用された）を実施した。ちょうどその 頃, 留学の話があり, 多くの研究者がアメリカを選ん だのに, 筆者は英国を選び, 科学技術庁の長期在外研 究員選抜試験を受け, 英国物理研究所に留学する機会 を得た。Mr. C. Scruton は筆者の身元引受人を承諾して くれた。研究所滞在中はガス卜応答の解析を試みたり, 氏より指示のあった 3 自由度の部分模型実験（気流方 向の自由度も持たせる)の実験装置を設計したりした。 また, 実橋梁の試験としてオーストラリアの代表的斜 張橋である Lower Yarra 橋の風洞試験を行ない, Mr. D.E. Walshe と連名の報告書をとりまとめたりもした。 研究所では建築物(New York の World Trade Center の近 接建物の空力干渉), 煙突(デンマークとは異なり strake
を巻き付けることによる防振)さらには森林を越える 気流など幅広い研究もなされていた。

当時はロンドンに居住する人も少なく, グローブナ 一通りにあった日本大使館の領事部に入り込み, 関係 者から楽しい話を聞かせていただいたり, 旅券に旅行 先を追記して頂いたりすることができた。そんな中， 日本から企業・団体の方が研究所見学に訪れ, そのた びに通訳の役割を持たされた。確かに当時のイギリス は, 航空機はアメリカに, また, 船舶は日本に遅れを とる状態ではあったが, 帰り際に多くの方が, “イギリ スからは得るものはない”と言われたのは大変残念で あった。

滞在中の来訪者に橋梁関係では小西一郎先生, 坂田 弘氏などが居られた。先生はScrutonの顔を見るなり，” 昨年訪問してのち，どのような論文を出したか “と極 めて単刀直入な質問をなされ, 同席していた筆者は驚 かされた。また, 坂田氏は部分模型を使って非定常空 気力を測定する手法を編み出された直後で, ご自身の 論文を披歴し解説して議論をされ, 正に道場破りとい った雾囲気を醸し出されていたのは懐かしい想い出で ある。

昭和 42 年に帰国した後は, 国内の吊橋や斜張橋など 長大柔形式橋梁の耐風設計に追われる毎日を過ごした。 それらの中には, 関門道路吊橋, 名港西大橋, 横浜港 ベイブリッジ，平戸大橋などが含まれる。

当時の耐風設計の基本的な考えは Theodorsen の平板 空気力を基本としてこれを吊橋補剛トラス・桁に転用 しょうとするものであった。しかし, 有限の厚みを持 つトラスあるいは妳に Kutta の条件などが成り立つは ずがない。

そこで, 流線型断面の補剛けたを提案したが, 気流 の剥離点が測定風速ごとに変化し, 3 分力係数が確定 できない兴みが生じた。解析的に推定した剥離点にト リップワイヤを取り付けて強制的に剥離点を固定する などの工夫をしたが，自信がなかった。そこで，乱流 研究の第一人者であられた谷一郎先生を訪れご意見 を頂いたが, 静止している場合でもよく解らないのに 運動中の模型では推定の方法がない, と宣告されてし まった。最近，曲面を持った補剛断面を持つ橋梁（例 えばメッシナ海峡計画案）が提案されているのをしば しば見受けるが，この種の問題は解決されているのか 不安である。

仕方なくブラッフな断面を基本とし，運動方程式の 外力項には実測の空気力值を取り込もうと考えるのが 
人情である。先の坂田氏の方法もこの考えに沿ったも のであろう。すでに航空機の分野では風路内で模型を 加振して非定常空気力を測定しょうとする幾つかの手 法が提案されていたが, 作用空気力に比して圧倒的に 大きい模型の慣性力を如何にして除去し, 空気力の測 定精度を上げるかが問題であった。坂田氏は慣性力を 電気回路で除去する方法を採用した。筆者は玩具の“弥 次郎兵衛”からヒントを得て, 機械的に慣性力を除去 する方法を用いた。この方法は当初はヒービングを対 象としたが, 後にはピッチングにも拡張した。吊形式 橋梁の桁形式補剛構にも発生する例が見られるように なった風琴振動の対策立案のためにも, 微小空気力を 正確に測れる計測装置は有力な武器となり, また, 完 成系のみならず，架設系の耐風性もストリップ理論に より検討することが可能になった。

話は反れるが昭和 40 年代にわが国では橋梁の建設 が活発に行われたが, 当時は競争設計が盛んな時代で あり，できるだけ鋼重を滅らすことに注力され，十分 な剛性を持たない橋梁が生み出された。その結果, 比 較的低風速領域で橋梁部材(例えば下路ランガー橋の 腹材など)の振動問題が発生し, 時には部材の疲労破断 などの事故も発生した。いわゆる風琴振動である。そ の対策として部材の剛性の増加, 断面形状の改善, さ らには振動減衰性の付加などの手段が用いられたが, その際にも非定常空気力測定装置は大きな威力を発揮 した。

\section{4. 大型風洞と全体模型実験}

周知のように, 長大吊形式橋梁の耐風性は吊構造部 の部分模型を用いたいわゆる部分模型試験で確認する のが一般的な手法であり，すでに紹介したように全体 模型を用いた本格的な風洞実験は Prof. F.B.Farquharson によるタコマ橋についてのものと, Dr. R.A.Frazer と Mr. C.Scruton が昭和 21 年から 6 年間に亘 り格納庫で行った実験のみであった。吹き上げあるい は吹き下げ風の効果を知るために, 前者では縮流胴の 終端部に翼列を配置することにより，また，後者では 風洞風は水平にしか吹送しないので風に対する迎え角 は模型全体を傾けて付け，そのために発生する重力の 水平成分の影響はばねによって打ち消す方法をとった。 本四架橋事業が進渉して対象橋梁が漸次長大化し, 明 石海峡大橋の建設が視野に入る頃には完成系のみなら ず，架設系の耐風性を確認する必要に迫られた。そこ で,すでに述べたように研究室では当時の計画中央支
間 $1500 \mathrm{~m}$ を念頭に縮尺 $1 / 100$ 模型用に吹き口寸法 32 $\mathrm{m}$ 幅の超大型風洞を建設しょうと計画した。しかも新 風洞では縮流胴と拡散胴を可動として, 風洞風に傾斜 風を発生できるように工夫をした。しかし, 諸般の事 情から実現せず，幻の計画に終わった。

その後明石海峡大橋の中央支間は一挙に $1990 \mathrm{~m}$ に 拡大されたが，それに伴い実施した実験では, 部分模 型と全体模型の結果の乘離が生じた。その原因のひと つには全体模型の縮尺比が小さくなるために幾何学的 ならびに力学的な相似に難点があったことによる。そ こで, 当時部分模型の最小縮尺比である $1 / 100$ と同程 度の規模の全体模型を収容できる測定部を持つ風洞の 建設を計画し, 事業主体の本四連絡橋公団と協議の上, 建設省土木研究所の構内に測定部断面 $41 \times 4 \mathrm{~m}$ を持つ 大型風洞施設を建設した。筆者は建設計画立案の段階 で建設場所を土研構内に決定した時点で建設省を退官 したので, 本風洞建設の具体化, それを用いての成果, さらには,橋梁耐風設計の象徵的存在であった本施設 のその後の消長については, ここでは触れないことと する。

\section{5. あとがきに代えて}

建設省土木研究所の勤務を終える少し前にニューヨ ークのマンハッタン周辺の橋梁群, とくに吊橋の見学 の機会を持った。特別にお願いをして橋台内を見せて 頂いた。理由は橋台には主ケーブルを通じて雨水が浸 入し易く, 橋台内は常に湿度が高い状態に置かれるた め, どのような防錆方法を採っているかを見たかった のである。その結果は予想通りの傷み方であった。一 部を除いて大部分の長大吊橋は第二次大戦までに架設 されたアメリカでは, ケーブル・ハンガーの腐食が問 題になっており, その張り替えが新聞記事になってい た。こうした諸外国での経験はわが国でも注視してお り, キメの細かい方法で対策が施されているのは周知 の通りである。

一方, 中小橋梁に目を向けると, 最近では内外を問 わずの疲労と腐食による破壊が大きな問題になってい る。橋梁は他の公共施設とともに重要な社会的な資産 であって, 消耗品と考えるべきではあるまい。橋梁を 消耗品と考えれば, 次代に伝えていく資産とはならな い。社会的な資産が積み重衫られる結果として, 豊か さに富んだ社会が形成され, 初めて, 美しい国作り, が出来るのである。橋梁は社会的な資産だが, 同時に, 私たちの時代の “しるし”でもある。こうして私たち 
が生きてきた時代のしるしを大切に維持保全すること なしに次々と抹殺せざるを得ない状況に追いやってい る現状を，私は許しがたいと思っている。自然の四季 のうつろいに映える橋梁の素晴らしさを落ち着いて楽 しめる時代を取り戻したいと考えるのは鳌沢すぎるも のなのだろうか。

文末になったが,これまでご指導戴いた多くの先生, および，ともに仕事に励んだ同僚・友人・後輩の方々 に心より感謝の意を表して筆を擱く。

平成 19 年 8 月 15 日 終戦記念日に記す 